\title{
Advertising Strategies and Their Influence and Impact on the Perception and Interactive behavior of Women Consumers
}

\author{
U.C. Sharmaa , Swati Sharma ${ }^{b^{*}}$ \\ aFaculty of Commerce and Business Administration, MMH College Ghaziabad, U. P., India \\ ${ }^{b}$ Department of Commerce and Business Administration), MMH College Ghaziabad, U. P., India \\ Email Id: swatisharma.ipem@gmail.com
}

\begin{abstract}
Advertisement has a very significant role in current era as it decides the attitudes and insights of individuals and society which outstandingly effects the customer buying behavior. In any business success when it attracts and retains the Women Consumers with profit and this goal is achieved when company builds a strong Women Consumer perception for its product or service. All the big guns have made significant attempts to ensure quality advertisement and fabrication of strong Women Consumer perception through suitable ways that positively affects the Women Consumer buying behavior because people get knowledge about product through advertisement and other promotional tools and develop perception through company's activities and his previous experience with that company and past purchase accordingly.

The purpose of this paper is to cover the gap from the previous literature with regard to the cognitive and the behavioral component of attitude of consumers. The literature was scant in examining the influence of the mostly used traits on the purchase behavior and the switching behavior of consumers. Therefore, this research paper examines the impact of different marketing strategies used by the advertisers on the components of the attitude of the consumers.
\end{abstract}

Key Words: Advertisement, Buying behavior, Women Consumer, Impact, Attitude.

PAPER/ARTICLE INFO

RECEIVED ON: 12/04/2020

ACCEPTED ON: $19 / 06 / 2020$

Reference to this paper should be made as follows:

U.C. Sharma, Swati Sharma (2020), "Advertising Strategies and Their Influence and Impact on the Perception and Interactive behavior of Women Consumers", Int. J. of Trade and Commerce-IIARTC, Vol. 9, No. 1, pp. 164-173 


\section{INTRODUCTION}

Advertising is a form of marketing communications used to promote or sell something, usually a business's product or services. Advertising is considered to be a significant and vital element for the economic growth of the marketer and different company in competition Advertising is usually a paid form of publicity by some sponsors and reach through various traditional media such as televisions, commercial radios advertisement, outdoor advertising, newspaper, magazine mail or modern media such as blogs, website and text message. Furthermore, the developments and technological advancement have turned advertising to a more pervasive and powerful in its impact and affect.

First of all, the perception of the consumers towards the traits was measured by the factor analysis approach. Second, the impacts of the character on the purchase behavior of consumers were studied using regression analysis. Then descriptive statistics approaches were used to analyze the switching behavior and the most crucial tactic used in the advertisement.

The study of Women Consumer behavior assumes that Women Consumers are actors in the marketplace. The perspective of role theory thinks that Women Consumers play various roles in the market. Starting from the information providers, from the user to the payer and the disposer, Women Consumers play these roles in the decision processes. According to Engel, Blackwell, and Mansard, Women Consumer behaviors is the action and decision processes of people who buy goods for their personal use. "According to Louden and Bitta," Women Consumer behavior is the decision process and physical activity, which individuals engage in while evaluating, acquiring, using or disposing of goods and services.

\section{REVIEW OF LITERATURE}

Various studies have been examined the effectiveness of advertising within the past decade. The standard measures of advertising effectiveness embrace ad recall, ad recognition, full awareness, clicks or click-through rate, perspective towards the ad and therefore the whole, and buy thought. Of those standard measures, attitudes toward the ad, click an advertisement, and talent to recall ad area unit, the main focus of this study. The effectiveness of those three measures was assessed by their ability to predict purchase calls. Advertising, publicity, and packaging area unit mass communication tools obtainable to marketers. As its name suggests, mass communication uses constant message for everybody in Associate in Advertisement audience. Today, advertising is also outlined in an exceedingly different means. We tend to could describe it as a method of communication with the users of a product or service. Advertisements area unit messages procured by people who send them and area unit meant to tell or influence folks that receive them. Thus they outline it as a paid, non-personal communication through various media by business companies, a non-profit organization, and people World Health Organization area unit in how known within the advertising message and World Health Organization hope to tell or persuade members of a specific audience thinks that advertising is employed to ascertain a necessary awareness of the merchandise or service within the mind of the potential client and to create up information concerning it. The perspective toward the ad is outlined because the predisposition to reply in a very favorable or unfavorable manner to a specific advertisement and has two completely different elements: an affection element reflective the emotions induced by the ad and a psychological feature component thoughtful however well created and helpful the 
Advertising Strategies and Their Influence and Impact on the Perception and Interactive behavior of Women..... U.C. Sharma, Swati Sharma

message and the knowledge in it's thought-about to be. The studies conducted by Mitchell and Olson (1982) were among the first to demonstrate that the way consumers assess an ad provides an impact on brand attitude above the ability of the ad to communicate information on brand attributes. Both the attitude toward the brand and the purchase intention are influenced, according to the above authors, not only by beliefs about the brand but also, to a considerable extent, by the attitude toward the ad.

The main objective of this paper is to identify the mechanisms through which the thoughts and feelings evoked by an ad lead to a favorable attitude toward the ad and how (and under what conditions) this attitude leads, in turn, to a pleasant brand attitude. Thus, MacKenzie, Lutz, and Belch (1986) developed a model, supported by considerable empirical evidence, using which to explain the impact of advertising on consumers' attitudes. According to their model, the Consumer's exposure to a particular ad trigger affective (feelings) and cognitive (thoughts) responses. These feelings and beliefs influence the Consumer's attitude toward the ad and the cognitions that relate to the brand, which also affect attitude toward the brand. Thus, the attitude toward the ad affects attitude toward the brand both directly and indirectly through shaping brand cognitions. The reasoning is as follows: consumers with a favorable attitude toward an ad are more receptive to arguments in favor of the brand. For example, a consumer who likes the commercial for the Milka chocolate is less likely to consider the disadvantages of the brand (higher price), but rather, she will only have in mind its advantages as the ad contains humor and originality.

In the analysis that LeRoux makes concerning the influence of the attitude toward the ad on brand attitude, he proposes a model in which the attitude toward the ad can be explained using three categories of reactions: reactions triggered by the execution of an ad, emotional responses and cognitive reactions triggered by arguments presented in the ad. Concomitantly, LeRoux elaborated a matrix with results triggered by advertisements, by identifying for each type of response a series of specific perceptual factors: positive cognitive reactions (relevance, credibility, realism, creativity, imagination, familiarity), adverse cognitive reactions (confusion, hate), positive affective responses (entertainment, humor, vitality, activity, liking, empathy, sensuousness), negative emotional responses (irritation, sluggishness) (Dobre, 2005, p.172).

Concerning the period during which the effect of the favorable attitude is manifested, some studies claim that this effect persists over time while other studies show that it is short-lived. Thus, it has been suggested that in the case of a likable ad, which draws so much attention to itself that brand attributes in the ad are not processed by the Consumer, after a time lag, the ad liking decays. The Consumer has weaker attitudes to the brand than if the announcement had not taken away attention from brand attributes (Chattopadhyay, Nedungadi, 1992).

The effect of ad liking on brand attitude varies according to the nature of the promoted product. According to several studies by Brown and Stayman (1992), the effects are more significant for novel and unfamiliar brands than for well-known ones. At the same time, the impact of ad liking on brand liking is also significantly reduced after the Consumer has tried the brand (Smith, 1993). On the other hand, brand cognitions, shaped as a result of exposure to the ad, play a deciding role in determining the brand attitude in the case of natural products. The Consumer's level of 
involvement in the purchasing decision is another factor that bears on the influence exerted by the ad attitude on the brand attitude.

According to the elaboration likelihood model, the effect of peripheral cues on brand attitude is much higher under low-involvement conditions. Consequently, one can infer that the impact of view to the ad on brand attitudes is more significant under low-involvement conditions since the feelings that play a vital role in shaping attitudes to the announcement are considered to be peripheral cues (Homer, 1990). The results of the studies conducted on this subject are different, which means that the attitude to the ad often contributes to brand positions under both high and low involvement on the part of the Consumer. It is explained through the fact that the different components of view to the ad (evaluation of the ability to entertain and inform the Consumer) require both central and peripheral processing of the message (MacKenzie, Lutz, 1989). Thus, while under low-involvement conditions the feelings evoked by the ad are a significant contributor to ad liking, under high involvement conditions both senses and the ad's usefulness jointly contribute to ad liking (Miniard, Bhatla, Rose, 1990).

To better understand how the ad attitude affects brand attitude, it is essential to see what kind of attitude consumers develop toward the ad itself. If the feelings that the ad create are positive and if the way the announcement is made and the information in it is evaluated favorably, then the ad should elicit a favorable attitude toward itself (Greene, 1992). An ad can be liked either because it is entertaining or because it is considered useful, or both. According to Greene's model, the attitude to the ad is influenced by the following factors: attitude toward advertisements in general, attitude toward the source of the message (advertiser), the mood of the viewer and the feelings evoked by the announcement, the evaluation of the execution characteristics of the ad (the format of the message), the viewer's perceptions of the credibility and believability of the ad. On the other hand, Solomon lists the following determining factors which affect the ad attitude: attitude toward advertiser, evaluation of the ad's execution characteristics (the message format), the Consumer's mood and the feelings evoked by the announcement, the ability of the ad to trigger reactions on the part of the Consumer (Solomon, 2003, p. 230).

The character of the executional delineates one of the critical factors shaping the angle of the ad. Different artistic ways might cause an equivalent overall level of perspective on the part of the customers. During this context, the identification of aesthetic characteristics that create a poster to be likable becomes essential. The analysis of advertising's impact on consumers' attitude toward different product and service categories (household products, private use products, long term use products, luxury products, banking, and financial services, tourism and entertainment services) reveal insignificant differences among statistical averages (more results are available on request). According to the answers given, over $40 \%$ of interviewees stated that they seldom or very seldom take ads into account when they adopt an attitude toward different product and service categories.

\section{Research Methodology}

Secondary sources of data have been used.

\section{RESEARCH LIMITATIONS/IMPLICATION}

This research paper has some limitations. The research area is restricted to the urban population of three districts of Punjab only, e.g., Amritsar, Jalandhar, and Ludhiana; because of this, the 
Advertising Strategies and Their Influence and Impact on the Perception and Interactive behavior of Women.....

U.C. Sharma, Swati Sharma

results cannot be generalized for other areas. Due to the changing behavior and the attitude, income level, and media, the responses of the Consumer in the present studies may not be relevant in future periods. The study was confined for working women consumers only and did not represent the whole full population.

\section{Nature of WoMen CONSUMER Behavior}

1. Influenced by various factors:

The multiple factors that influence Women Consumer behavior are as follow:

A. Marketing factors such as product designs, prices, promotion, packaging, positioning, and distributions.

B. Personal factors, viz., as age, gender, education, and income levels.

C. Psychological factors such as buying motive, perception of the products, and attitude toward the products.

D. Situational factors, e.g., physical surroundings at the time of purchases, social surroundings, and time factors.

E. Social factors, for example, social status, reference groups, and families.

F. Cultural factors, like faith, social class - caste, and sub-castes.

2. Undergoes a constant change: Women shopper behavior is volatile. It keeps on everchanging over an amount of your time reckoning on the character of the product. For example, children like colorful and fancy footwear; however, as they grow old as teenagers and young adults, they like fashionable footwear. As mature and senior voters, they want a lot of sober footwear. The amendment in shopping for behavior could turn up because of many different factors like an increase in financial gain level, education level, and selling elements.

3. Varies from Women Consumer to Women Consumer: All Women Consumers do not behave in the same manner. Different Women Consumers behave differently. The differences in Women's Consumer behavior are due to individual factors such as the nature of the Women's Consumers, lifestyle, and culture. For example, some Women Consumers are technophilic. They go on searching and pay on the far side. Their means that. They borrow cash from friends, relatives, banks, and from time to time, even adopt unethical ways to pay on searching for advanced technologies. However, there are different girls shoppers World Health Organization, despite having surplus cash, don't go even for the regular purchase and avoid use and get of advance technology.

4. Vary from region to region and counties to county: There is a considerable variation in Women Consumer behavior vary across states, parts, and countries. For example, the action of the urban Women Consumers is different from that of the rural Women Consumers. A good number of rural Women Consumers are conservative in their buying behaviors.

The rich rural Women Consumers may not be liberal to spend money on extravagances despite having sufficient funds. In contrast, the urban Women Consumers are more inclined to lead a beautiful life and may even take a bank loan to buy luxury items such as cars and household appliances. The variation in Women Consumer behavior across the states, regions, and countries is the impression of their upbringing, lifestyles, and level of development. 
5. Information on Women Consumer behavior is relevant to the marketers: Marketers need to have a good knowledge of the Women Consumers' behavior. They need to study the various factor that influences the Women Consumers behavior of their target customer.

The knowledge of Women Consumer behavior enables them to take appropriate marketing decisions concerning the following factors:

a. Product design/model

b. Pricing of the product

c. Promotion of the product

d. Packaging

e. Positioning

f. Place of distribution

6. Leads to purchase decision: A positive Women Consumer behavior leads to a purchase decision. A Women Consumer might take the choice shopping for a product on the idea of various buying motives. The acquisition call results in higher demand, and also the sales of the marketer's increase. Therefore, marketers ought to influence Women's Consumer behavior to increase their purchases.

7. Varies from products to products: There is a variation in women's Consumer behavior for different products. Some Women Consumers may be quantitative while buying individual items or no amount of different things. As an example, teenagers could pay slowly on merchandise like cell phones and branded wears for unpleasant personal attractiveness; however, they might not pay on general and educational reading. A middle-aged person could spend less on wear; however, they could invest cash in savings, insurance schemes, pension schemes, and so on.

8. Improves standard of living: The shopping for behavior of the ladies customers could cause higher normal of living. A lot of an individual buys the products and services; the upper is that the normal of life. However, if an individual spends less on merchandise and services, despite having a decent financial gain, they deprive themselves of the upper standard of living.

9. Reflects status: The Women Consumer behavior is not only influenced by the state of a Women Consumer, but it also indicates it. The Women Consumer Behavior: Meaning and Nature - theintactone.com. https://theintactone.com/2019/10/27/pom-u2-topic-1consumer-behavior-meaning-and-nature/ (PDF) impact of social media on the buying behavior of the Consumer.

Source:https://www.researchgate.net/publication/330618244_impact_of_social_media_on_b uying_behaviour_of_consumerConsumers who own luxury cars, watches, and other items are considered belonging to a higher status. The luxury items also give a sense of pride to the owners. (PDF) impact of social media on the buying behavior of consumers. Source:https://www.researchgate.net/publication/330618244_impact_of_social_media_on_b uying_behaviour_of_consumer

\section{EFFECT OF ADVERTISEMENT ON WOMEN CONSUMER BUying BeHAVIOR}

Increased awareness: -Advertising and promotion offer a news function to Women Consumers. The Viewers of ads learn about new products and services available to them, much as they learn 
Advertising Strategies and Their Influence and Impact on the Perception and Interactive behavior of Women..... U.C. Sharma, Swati Sharma

about events in the original. (Source: https://www.slideshare.net/25Mksp/advertising-andbrand-management)These information functions have a neutral role. However, it provides facts without approval or disapproval from Women Consumers. Customer behaviors at this stage encompass expressions of curiosity.

Analysis of Features: - Women shoppers tend to possess a balanced response to advertising after they inspect the options of a product or service. These responses focus on a logical listing of all the useful aspects of the provision. This is often a rational response instead of AN emotional one.

Evaluation of Benefits: -When customers weigh benefits, they become emotionally involved with advertising and promotion. The way Women Consumers identify the product or service can make them happier, improve their lives, or give them pleasure. This part of the Women's Consumer response is illogical and can lead to impulse buying and competition to obtain the product.

Reminders: -Repeated advertising messages affect Women's Consumer behavior. This repetition serves as reminders to the Women Consumers. Gernal behavior that stems from reminders includes suddenly thinking of products while shopping and making decisions to be bought as if it had been on the Women Consumer's "to-do" list.

Promotion of Loyalty or Alienation: -Women Consumer behavior splits between loyalty and alienation depending on how well the product lives up to its advertising benefit. Corporate action - such as scandal or charity works - can also affect alienation and loyalty responses. Once the Women Consumer makes this choice, advertising and promotion are not likely to undo that decision.

- Advertising creates demand.

- It promotes the marketing system.

- It makes customers aware of the prices and attributes of the product leading to higher sales.

- It brings awareness to the masses.

- Marketing researchers and advertising research can assess women's Consumer demand.

Social dimensions of advertising: It informs the society of assorted merchandise offered, their technology, uses, and the way the community will enjoy innovations, like credit cards, debit cards, golden cards, world cards, mobile phones, travel offers, etc. Advertising conjointly educates the individuals and, therefore, society against the hazards of life. Cancer, Smoking is injurious to health, risky driving, higher late than ne'er. Similarly, we've driven against pollution, against population explosion, etc. Advertising shouldn't deceive society. It shouldn't manipulate the ladies' customers against their can. They will get exploited by desirability Psychological facets: One aspect of psychological advertising is that drinking of Alcohol, Beer, Wine shouldn't be targeted on the kids or those below the age of twenty-one. Girls in society are essential concerning obscene ads and promoting sexual disposition within the advertising, i.e., fashion designer. There's heaps of criticism on advertising against sexual appeals and status. They abase girls as being sex objects. Such ads may be for cosmetics, intimate apparel, and different merchandise employed by girls. Once a girl's client tries to shop for a product. He features a ton of decisions before him. He gets target-hunting by the family, my friends, by advertisements, by the employee, and therefore, the girl's client gets confused and infrequently feels that he has 
created a wrong alternative. He undergoes each pre and post-purchase dissonance, and consequently, the vender attempt to take away his anxiety by reinforcing his option.

Communication task: - Advertising interconnects and captures the attention of the buyer. It communicates through stories, through episodes, through tables and charts. The communication must be interpreted in the same manner that it is intended. It also brings attitudinal changes and changes the faiths and beliefs of the Women Consumer.

\section{CONCLUSION}

The study reveals that advertising on the behavior of Women Consumer plays a significant role in selling products. Women Consumer behavior and advertising are active fields, in terms of practice and scientific training. For example, the television commercials that appear in the year 2019 have little in common with those from the 1970s. Advertising research styles have involved and advanced, partly through the influence of improved technology and access to advanced theories and methods. Consumers who state they are often affected by ads when forming opinions about household current use products view advertising as an information source on products and services and, to a certain extent, a source of entertainment, with a favorable attitude toward demonstration, testimonial, or life scene ads. The preferred endorsers in the ads are experts, TV stars, and regular consumers.

The results shows that frequent exposure, evaluation of products, and sexual appeals have a significant impression on the mind of consumers, which governs the impact of advertising tactics. Further, the results assessed that information, pricing element, the image of the company, and sexual appeal are the other vital trait influencing the cognitive attitudes of consumers. The consumers switch to advertising products, which indicates the behavioral change with the impact of advertisement.

\section{REFERENCES}

[1]. Batra, Rajeev , L. Ray,Michael ( September 1986), Affective Responses Mediating Acceptance of Advertising, Journal of Consumer Research, Volume 13, Issue 2, Pages 234249, https://doi.org/10.1086/209063

[2]. Davis, H. L., Rigaux, B. P. (1974), Perceptions of Marital Role in Decision Processes, Journal of Consumer Research, Vol.1, pp. 51-62.

[3]. Fu1, J.R., and Chen, J. H. F. (2012). An Investigation of Factors that Influence Blog Advertising Effectiveness, International Journals of Electronic Business Management, Vol. 10, No. 3, pp. 194-203. http://yadda.icm.edu.pl/yadda/element/bwmeta1.element.ekonelement-000171296053

[4]. Furaiji, F., AatuszyDska, M., Wawrzyniak, A. (2012). An Empirical Studies of the Factors influencing Consumers Behavior in the Electric Appliances Markets, Contemporary Economics, Vol. 6(3), pp. 76-86, DOI: 10.5709/ce.1897-9254.52.

[5]. Furaiji, F., Wsikowska, B. (2012), Badaniepreferencjizakupowychkobieti $\mathrm{m}^{\prime} \mid$ czyznmetodzbiorowprzybli|\onych,in: Zachowaniakonsumenckie - badania, uwarunkowaniaro|nice, E. Rudawska, E. Frckiewicz (eds.), Handel Wewn'trzny, Vol.I , pp. $26-35$. 
Advertising Strategies and Their Influence and Impact on the Perception and Interactive behavior of Women.....

U.C. Sharma, Swati Sharma

[6]. Gill, S., Stockard, J., Johnson, M., Williams, S. ( 1987 ), Measuring genders differences: < e expressive dimensions and critique of androgyny scale, Sex Roles, Vol. 17, pp. 375-400. http://yadda.icm.edu.pl/yadda/element/bwmeta1.element.ekon-element000171296053

[7]. Goldsmith, R. E., Lafferty, B. A. (2002), Consumer's response to websites \& their influence on advertising effectiveness Internet research, Journal of Electronic Networking Application and Policy, Vol. 12(4), pp. 318-328. http://yadda.icm.edu.pl/yadda/ element/bwmeta1.element.ekon-element-000171296053

[8]. Haas, A. (1979), Males and females spoke language difference: Stereotypes and evidence, Psychological Bulletins, Vol. 86 (3), pp. 616-626, DOI: 10.1037/0033-2909.86.3.616. https:// bazekon.uek.krakow. pl/171296053

[9]. Hatala, R., Case, S. M. ( 2000 ), Examining the influences of genders on medical students decision making, Journal of Women's Health and Gender-Based Medicine, Vol. 9, pp. 617-623.

[10]. Hawkins, K., Power, Ch. B. (1999), Genders difference in questions asked during small decision-making group discussions, Small Group Researches, Vol. 30, pp. 235-256. https:// bazekon.uek.krakow.pl/171296053

http://yadda.icm.edu.pl/yadda/element/bwmeta1.element.ekon-element000171296053

[11]. http://yadda.icm.edu.pl/yadda/element/bwmeta1.element.ekon-element000171296053

[12]. Hyuang, C. (2010), The 4G Mobile phone consumer preference predictions by using the Rough Set Theory and flow graphs. Phuket, Thailand: Technology Management for Global Economic Growth (PICMET).

[13]. K'dzior, Z. et al. (2005), Badaniarynku. Metody, zastosowania, Warszawa: PWE.

[14]. Kaczmarczyk, S. (2003), Badaniamarketingowe. Metodyitechniki, Warszawa: PWE.

[15]. Kardes, F.R., Cline, T.W., Cronley, M.L. (2011), Consumers Behavior. Science and Practice, South-Western, Cengage Learning.

[16]. Keegan, W., Moriarty, S., Duncan, T. (1992), Marketing, Englewood Cliffs, New Jersey: Prentice-Hall.

[17]. Komorowski, J., Pawlak, Z. , Polkowski, L., Skowron, A. (1999), Rough sets: A tutorial in Rough fuzzy hybridizations: A new trend in decision making, S.K. Pal and A. Skowron (eds.), Singapore: Springer - Verlag, pp. 3 - 98.

[18]. Kotler, P. (1994), Marketing. Analiza, planowanie, wdra|anieikontrola, Warszawa : Gebethneri S-ka.

[19]. Kotler, P., and Armstrong, G. (2008)." Principles of marketing" 12th ed., Pearson Prentice Hall, 396-398.

[20]. Kotler, P., Armstrong, G . , Saunders, J., Wong, V. (2002), Marketing . Podr'cznikeuropejski, Warszawa: PWE._http://yadda.icm.edu.pl/yadda/element/bwmeta1.element.ekonelement-000171296053

[21]. Kotler, P., Armstrong, G. (2007), Principles of Marketing, Upper Saddle River: Prentice-Hall.

[22]. Kotwal N, Gupta, N \& Devi, A (2008), Impact of TV advertisements on buying patterns of adolescent girls, Journal of Social sciences, vol. 16 no. 1 
Advertising Strategies and Their Influence and Impact on the Perception and Interactive behavior of Women.....

U.C. Sharma, Swati Sharma

[23]. Kraft, H ., Weber, J. M. (2012), A Look at Genders Differences and Marketing Implications, International Journal of Business and Social Science, Vol. 3, No. 21, pp. 247-253.

[24]. Kumar, Dr. D. Prasanna \&Venkateswara Raju, K.(2013). The Roles of Advertising in Consumer Decision Making IOSR Journal of Business and Management, 14 (4), 37-45.

[25]. Lancaster, G . (2005). Research Methods in Management. A concise introduction to researches in management and business consultancies. Jordan Hill, Oxford: Elsevier ButterworthHeinemann Linacre House.

[26]. Liou, J., Tzeng, G. (2010), A dominance-based Rough Set Approach to customer behavior in the airline market, Information Sciences, Vol. 180, Issue 11, pp. 2230-2238, DOI:10.1016/j.ins.2010.01.025.

[27]. Meyers-Levy, J., Maheswaran, D. (1991), Exploring Males' and Females' Processing Strategies: When and Why Do Differences Occur in Consumers' Processing of Ad Claims, Journal of Consumer Research, Vol. 18, pp. 63-70.

[28]. Mokhlis, S., Salleh, H. S. (2009), Consumer Decision-Making Styles in Malaysia: An Exploratory Study of Gender Differences, European Journals of Social Sciences, Vol .10, No 4, pp 574-584.

[29]. Narayan, S. M., Corcoran-Perry, S. (1997), Line of reasoning as a representation of nurses' clinical decision making, Research in Nursing and Health, Vol. 20, pp. 353-364.

[30]. R.A. Peterson, W.D. Hoyer, and W.R. Wilson (eds). (1986). The Role of effect in Consumer Behavior. Lexington, MA: Lexington Books, 53-86.

\section{Websites Links}

[1]. http://www.yourarticlelibrary.com/marketing/market-segmentation/consumerbehaviour-meaningdefinition-and-nature-of-

[2]. http://study.com/academy/lesson/what-is-consumer-buying-behavior-definition-typesquiz.html

[3]. http://shodhganga.inflibnet.ac.in/bitstream/10603/46970/1phd\%20thesis\%20ram\%20dhe eraj\%20business\%20admin...pdf

[4]. http://iosrjournals.org/iosr-jbm/papers/Vol14-issue4/F01443745.pdf

[5]. http://smallbusiness.chron.com/effect-advertising-promotion-consumer-behavior26196.html

[6]. http://www.irssh.com/yahoo_site_admin/assets/docs/6_IRSSH-710-V6N2.39115145.pdf

[7]. http://www.daaam.info/Downloads/Pdfs/proceedings/proceedings_2012/1047_Dinu\& Dinu.pdf

[8]. http://www.imd.inder.cu/adjuntos/article/398/Consumer\%20Behaviour\%20and\%20Adv ertising\%20Management.pdf 